PRZEGLĄD NAUK HISTORYCZNYCH 2016, R. XV, NR 2

http://dx.doi.org/10.18778/1644-857X.15.02.12

ANDRZEJ M. BRZEZIŃSKI

UNIWERSYTET ŁÓDZKI

\title{
Powstanie, organizacja i program dzialania Polsko-Szwedzkiego Komitetu Współpracy Kulturalnej przy Ministerstwie Wyznań Religijnych i Oświecenia Publicznego w 1936 roku
}

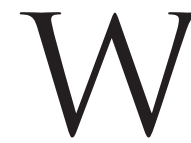

okresie międzywojennym Ministerstwo Spraw Zagranicznych (MSZ) oraz Ministerstwo Wyznań Religijnych i Oświecenia Publicznego (MWRiOP) podejmowały działania w zakresie nawiązywania i rozwijania stosunków intelektualnych Polski z zagranica zazwyczaj doraźne i bez należytej koordynacji. MSZ nie dysponowało wyspecjalizowaną komórka w zakresie promowania polskiej kultury i nauki zagranica czy - szerzej rzecz ujmując - realizowania „dyplomacji kulturalnej”. Częściowo zadanie takie starało się spełniać MWRiOP, w którego strukturze istniał Wydział Nauki. W podejmowanych przez oba ministerstwa działaniach dawały o sobie znać różnice zdań zarówno w kwestiach merytorycznych, jak i personalnych, a przede wszystkim brak odpowiednich środków finansowych na przeprowadzenie zamierzonych akcji ${ }^{1}$.

* Wydział Filozoficzno-Historyczny, Instytut Historii, Katedra Historii Powszechnej Najnowszej.

${ }^{1}$ Por. J. Róziewicz, H. Róziewicz, Z dziejów międzynarodowych kontaktów naukowych Polski w latach 1919-1939, „Problemy Polonii Zagranicznej” 1974, t. IX, s. 339-378; P. Łoss ow ski, Z problemów wspótpracy naukowo-kulturalnej z zagranica $w$ okresie II Rzeczypospolitej, „Dzieje Najnowsze” 1988, nr 1, s. 143-152; Historia nauki polskiej, red. B. Suchodolski, t. V (1918-1951), cz. 1, Wrocław 1992, s. 162-165. 
$\mathrm{Na}$ początku lat dwudziestych minionego stulecia instytucja kształtująca stosunki intelektualne Polski z zagranicą była Polska Akademia Umiejętności (PAU) w Krakowie. Od 1921 r. PAU miała zgodę władz państwowych na bezpośrednią współpracę z zagranicznymi placówkami naukowymi, co uważano wówczas za najlepszą formę kontaktów nauki polskiej z zagranica ${ }^{2}$. Powołanie w $1922 \mathrm{r}$. przez Ligę Narodów Międzynarodowej Komisji Współpracy Intelektualnej (MKWI) w celu organizowania i rozwijania życia intelektualnego w skali międzynarodowej stwarzało dla Polski możliwość włączenia się w planowany, nowatorski system współpracy umysłowej. W styczniu 1923 r. przy Kasie im. Józefa Mianowskiego powstała trzyosobowa Komisja do spraw Ligi Narodów, która stanowiła „łącznik" między polskim instytucjami naukowymi a MKWI w Genewie ${ }^{3}$. W 1924 r. powołano Polską Komisję Międzynarodowej Współpracy Intelektualnej (PKMWI). Jej zadaniem było włączenie polskiej nauki i kultury w system międzynarodowej współpracy intelektualnej w ramach Ligi Narodów. Przewodniczacym PKMWI był Karol Lutostański - prezes Kasy im. Józefa Mianowskiego, wybitny prawnik cywilista, profesor Uniwersytetu Warszawskiego W skład komisji, obok przedstawicieli PAU, Kasy im. Józefa Mianowskiego oraz ważniejszych ośrodków życia umysłowego w Polsce, wchodzili delegaci MSZ i MWRiOP w celu korygowania działań komisji zgodnie $z$ założeniami polityki RP wobec Ligi Narodów i poszczególnych krajów. Oba ministerstwa wspierały finansowo działalność PKMWI, ale były to ośrodki niewystarczające do realizacji zadań komisji podejmowanych w ramach przedsięwzięć inicjowanych przez MKWI ${ }^{4}$.

PKMWI promowała w świecie polską kulturę i naukę, a jednocześnie umożliwiała poznawanie w Polsce życia intelektualnego innych krajów. W zakresie współpracy uniwersyteckiej komisja inspirowała

${ }^{2}$ Por. J. P is k u r e w i c z, Prima Inter Pares. Polska Akademia Umiejętności w latach II Rzeczypospolitej, Kraków 1998, s. 56-57.

3 A.M. Brzeziński, Polska Komisja Międzynarodowej Wspótpracy Intelektualnej (1924-1939), Łódź 2001, s. 11 i n.

${ }^{4}$ W 1924 r. K. Lutostański zwracał uwagę MSZ, że Komisja nie ma „żadnych własnych źródeł dochodu”. Ponieważ jednak „spełnia funkcje bezpośrednio zahaczajace interes Państwa", zwracał się do ministra spraw zagranicznych o przyznanie komisji "stałej pomocy materialnej” (Biblioteka Uniwersytetu Warszawskiego, Oddział Rękopisów [dalej: BUWOR], Materiały K. Lutostańskiego, $\mathrm{nr}$ akc. 160, teczka 30, pismo bez daty dziennej). Prawdopodobnie dopiero od 1926 r. PKMWI otrzymywała od MSZ doraźne finansowe wsparcie. W drugiej połowie lat dwudziestych i w latach trzydziestych stałej subwencji na działalność Komisji udzielało także MWRiOP w postaci rocznych „zasiłków”. 
wymianę profesorów, stypendystów, studentów, publikacji naukowych oraz programów i informatorów o studiach. Uczestniczyła $\mathrm{w}$ akcji rewizji podręczników szkolnych w celu wyeliminowania $z$ nich treści mogących wzniecać animozje między narodami. Popularyzowała wiedzę o Polsce za granica w środowisku młodzieży szkolnej i wśród dorosłych przez organizowanie międzynarodowej korespondencji szkolnej oraz kursów wakacyjnych o „cywilizacji polskiej" dla cudzoziemców. Funkcjonujące w ramach komisji dwie instytucje autonomiczne - Polskie Towarzystwo Ochrony Prawa Autorskiego i Centralny Komitet Polskich Instytucji Nauk Politycznych - przyczyniły się do rozszerzenia kontaktów międzynarodowych Polski w zakresie prac nad kodyfikacja prawa autorskiego oraz nauk politycznych ${ }^{5}$.

Zmiana założeń MSZ i MWRiOP wobec udziału Polski w międzynarodowej współpracy intelektualnej następowała od połowy lat trzydziestych. Dyplomacja polska, kierowana od 1932 r. przez Józefa Becka, zajmowała wobec Ligi Narodów, tracacej autorytet w stosunkach międzynarodowych, coraz większy dystans i uznawała potrzebe jej zreformowania ${ }^{6}$. Choć nie podważano organizacji współpracy umysłowej w ramach Ligi Narodów, a w związku z tym dotychczasowej roli PKMWI, to coraz większe znaczenie przywiazywano do współpracy intelektualnej Polski z zagranica opartej na porozumieniach dwustronnych.

Do połowy lat trzydziestych Polska miała podpisane tego typu umowy, różniące się pod względem formalnoprawnym, zaledwie z kilkoma państwami. Układy dotyczące "stosunków naukowych, szkolnych i literackich" były zawarte z Francja (9 maja 1923 r.), Belgią (1 września 1925 r.), „porozumienie dotyczące stosunków naukowych, szkolnych i artystycznych" $z$ Jugosławia (2 grudnia 1931 r.) a konwencje o „współpracy kulturalnej” $z$ Węgrami (21 października 1934 r.) i Bułgaria (8 kwietnia 1935 r.) ${ }^{7}$. W MWRiOP tłumaczono ten stan rzeczy zaabsorbowaniem „najbliższymi i najważniejszymi troskami i zadaniami: organizacją szkolnictwa

${ }^{5}$ Międzynarodowa Wspótpraca Intelektualna w roku 1931/32. Sprawozdanie Sekretarza Polskiej Komisji Międzynarodowej Współpracy Intelektualnej, Warszawa 1933; Polska Komisja Międzynarodowej Wspótpracy Intelektualnej na progu 1936 r., Warszawa grudzień 1935.

${ }^{6}$ J. Beck, Przemówienia, deklaracje, wywiady 1931-1937, Warszawa 1938, s. 259-261.

${ }^{7}$ E. Zdrojews ki, Umowy $w$ zakresie stosunków kulturalnych Polski $z$ innemi państwami, „Oświata i Wychowanie” 1936, R. VIII, z. 2, s. 223-236. 
i oświaty oraz regulowaniem spraw podnoszenia kultury naszego kraju”. Ministerstwo „nie miało ani dość czasu ani środków, aby w krótkim stosunkowo okresie, bo okresie zaledwie lat kilkunastu”, zorganizować „na większą skalę” stosunki kulturalne Polski $z$ zagranica 8 .

Szwecja była kolejnym państwem, z którym MWRiOP zamierzało podpisać porozumienie służące organizacji, rozwojowi i pogłębieniu wzajemnych stosunków kulturalnych i naukowych. Okolicznością sprzyjająca zawarciu stosownej umowy były istniejace od lat pozarządowe kontakty intelektualnych elit obu krajów. Od 19 lutego 1926 r. działało w Sztokholmie Towarzystwo Szwedzko-Polskie (Svensk-Polska Föreningen) skupiające polityków, działaczy gospodarczych, przedstawicieli swiata kultury i nauki. W 1932 r. Towarzystwo ofiarowało Uniwersytetowi Jagiellońskiemu księgozbiór 800 tomów dzieł szwedzkich i podjęło decyzję o subsydiowaniu lektoratu języka szwedzkiego ${ }^{9}$. Lektorat prowadził Rudolf Mahr, który doktoryzował się na krakowskiej uczelni ${ }^{10}$. Dzięki wsparciu Towarzystwa w roku akademickim 1934/1935 uruchomiony został lektorat języka szwedzkiego na Uniwersytecie Poznańskim prowadzony przez dr. Franciszka Böhma ${ }^{11}$.

Ogromna rolę w rozwijaniu szwedzko-polskich intelektualnych kontaktów odgrywał Karl Gustaw Fellenius - inspektor Ministerstwa Skarbu, pisarz i dziennikarz, wieloletni sekretarz Towarzystwa.

\footnotetext{
${ }^{8}$ Sprawozdanie $z$ dotychczasowej działalności Ministerstwa Wyznań Religijnych i Oświecenia Publicznego w zakresie stosunków kulturalnych ze Szwecją (bez daty dziennej, luty 1936 r.), Archiwum Akt Nowych w Warszawie [dalej: AAN], MWRiOP, teczka 281, k. 483.

${ }^{9}$ Lektorat szwedzki w Krakowie, "Ilustrowany Kuryer Codzienny”, 14 V 1932, nr 132, s. 7; K.G. Fallenius, Kilka uwag o celach i działalności „Szwedzko-Polskiego Towarzystwa” w Sztokholmie, „Przegląd Współczesny” 1932, t. XL, nr 117 (styczeń), s. 124-127. Por. A. Stan is zewski, Działalność Towarzystwa Szwedzko-Polskiego na tle propagandy antypolskiej $w$ Szwecji $w$ okresie międzywojennym, „Zapiski Historyczne” 2010, t. LXXV, z. 1, s. 97-114.

${ }^{10}$ W 1932 r. Rudolf Mahr obronił prace doktorska nt. The Scandinavian Elements in England and the Norse Elements in Old English napisana pod kierunkiem prof. Romana Dyboskiego (Z. Mazur, Sto lat Instytutu Filologii Angielskiej Uniwersytetu Jagiellońskiego, Kraków 2011, s. 11).

11 Towarzystwo Szwedzko-Polskie $z$ inicjatywy K.G. Felleniusa ofiarowało Uniwersytetowi Poznańskiemu 419 tomów dzieł szwedzkich i kilkadziesiąt numerów czasopism. Böhm był kierownikiem Oddziału nordyckiego utworzonego przy Seminarium filologii germańskiej (Kronika Uniwersytetu Poznańskiego za rok szkolny 1934/ 35 za rektoratu prof. dr. Stanisława Rungego i otwarcie roku szkolnego 1935/ 1936 w dniu 20 października 1935 roku, Poznań 1936, s. 127, 172, 181).
} 
Wielokrotnie przyjeżdżał do Warszawy, Krakowa i Wilna. Publikował i wygłaszał wykłady (ogółem ponad 70) na temat historii relacji polsko-szwedzkich, organizował zbiórkę ksiażek dla polskich bibliotek $^{12}$. Z towarzystwem sztokholmskim pozostawało w kontakcie polskie Towarzystwo Szerzenia Sztuki Polskiej wśród Obcych, podtrzymujacc stosunki polsko-szwedzkie w dziedzinie sztuki ${ }^{13}$.

Od 1927 r. działało w Warszawie Towarzystwo Polsko-Szwedzkie, którego celem było popieranie i rozwijanie kontaktów kulturalnych i stosunków gospodarczych między obu krajami ${ }^{14}$. W styczniu 1932 r., z inicjatywy K.G. Felleniusa i profesorów Uniwersytetu Jagiellońskiego, powstało w Krakowie Towarzystwo Polsko-Szwedzkie. Główną rolę w popularyzowaniu kultury Szwecji, jej przedstawicieli oraz kontaktów intelektualnych polsko-szwedzkich odgrywali: Władysław Konopczyński - historyk, poliglota, badacz stosunków polsko-szwedzkich; Roman Dyboski - filolog, historyk literatury angielskiej oraz Stanisław Wędkiewicz - romanista. Na łamach redagowanego przez siebie od 1922 r. „Przeglądu Współczesnego" Wędkiewicz sporo miejsca poświęcał zagadnieniom skandynawskim. Wśród autorów wydanych w miesięczniku artykułów byli m.in. wspomniany Fellenius i lektorzy szwedzcy: Birger Calleman $z$ Warszawy i F. Böhm z Poznania. W „Przeglądzie Współczesnym” publikowali także lektorzy polscy w Szwecji - Zygmunt Łakociński i Stanisław Sawicki. W 1932 r. ukazał się 117 numer miesięcznika, zredagowany w związku $z$ inauguracją działalności Towarzystwa Polsko-Szwedzkiego w Krakowie, zawierający artykuły wymienianych autorów na temat dotychczasowych i aktualnych stosunków kulturalnych polsko-szwedzkich ${ }^{15}$.

12 B. Tornquist-Plewa, Karl Gustaw Fallenius, wielki przyjaciel Polski, [w:] Zwierciadła Północy. Związki i paralele literatur polskiej i skandynawskiej, t. II, Warszawa 1992, s. 163 i n. Por. P. J aw orski, Polska niepodległa wobec Skandynawii 1918-1939, Wrocław 2001, s. 203-206.

${ }^{13}$ Sprawozdanie $z$ dotychczasowej działalności Ministerstwa Wyznań Religijnych i Oświecenia Publicznego... (bez daty dziennej, luty 1936 r.), AAN, MWRiOP, teczka 281, k. 485. Towarzystwo Szerzenia Sztuki Polskiej wśród Obcych powstało w 1926 r. pod auspicjami MSZ i MWRiOP (Statut Towarzystwo Szerzenia Sztuki Polskiej wśród Obcych, Warszawa 1926).

14 Towarzystwo Polsko-Szwedzkie miało sekcje propagandowa i odczytowa. Prowadziło kurs języka szwedzkiego. W 1929 r. liczyło ok. 120 członków („Nauka Polska. Jej potrzeby, organizacja i rozwój”. Materiały do spisu instytucji i towarzystw naukowych w Polsce. Suplement do t. VII, R. XII, Warszawa 1930, s. 295-296).

15 Pierwszy kontakt Wędkiewicza ze Szwecją, jej kultura i nauka nastapił w okresie I wojny światowej. Przebywał w Sztokholmie (od września 1916 r. do 
Polsko-szwedzkie relacje intelektualne wspierały doraźne działania ze strony czynników rządowych obu krajów. Od początku lat trzydziestych MWRiOP oraz MSZ subwencjonowały polsko-szwedzką współpracę naukową w dziedzinie badań morskich. Jako członkowie Stałej Międzynarodowej Rady Badań Morza w Kopenhadze, Polska i Szwecja współpracowały przez swych delegatów w badaniach morskich w zakresie biologii, planktonu, hydrografii i problemów rybackich. W ramach Bałtyckiego Komitetu Geodezyjnego oba państwa współpracowały w dziedzinie geodezji teoretycznej i praktycznej. MWRiOP wspierało finansowo wydawnictwa Instytutu Bałtyckiego w Toruniu mające poszerzać znajomość Polski w krajach skandynawskich i przyczyniać się do rozszerzania wzajemnych kontaktów naukowych i kulturalnych ${ }^{16}$. MWRiOP oraz MSZ opłacały istniejacy od roku akademickiego 1934/1935 lektorat języka polskiego na uniwersytecie w Lund, prowadzony przez Zygmunta Łakocińskiego. MWRiOP subwencjonowało lektoraty języka szwedzkiego na Uniwersytecie Warszawskim (Birger Calleman) i w Uniwersytecie Poznańskim (dr F. Böhm) ${ }^{17}$.

W 1930 r. MWRiOP otrzymało „Fundusz skandynawski” pochodzacy ze składek społecznych zgromadzonych w Szwecji i pozostałych państwach skandynawskich. Procenty od tego funduszu miały zasilać - według intencji ofiarodawców - budżet przeznaczony na powołanie i utrzymanie na Uniwersytecie Warszawskim Katedry języków skandynawskich ${ }^{18}$. Rzecznikiem ustanowienia takiej

lipca 1918 r.) jako delegat Naczelnego Komitetu Narodowego, a nastepnie Rady Regencyjnej. Por. Z. Ci e siels ki, Stanisław Wędkiewicz jako badacz i propagator Skandynawii, „Przegląd Zachodnio-Pomorski” 1969, z. 2, s. 83-92; Towarzystwo Polsko-Szwedzkie. Siedemdziesiąt lat działalności 1926-1996, Warszawa 1996, s. 5 i n. Wędkiewicz był ponadto członkiem komisji powołanych do realizacji porozumień dwustronnych o współpracy kulturalnej Polski z Francją i Rumunią (Archiwum Uniwersytetu Jagiellońskiego. Materiały S. Wędkiewicza, sygn. XXXIX.1).

${ }^{16}$ J. B o rowik, Pięć lat pracy Instytutu Battyckiego, 1927-1932, Toruń 1932.

17 Od 1931 r. MWRiOP organizowało $z$ pomoca PKMWI corocznie wakacyjne kursy dla cudzoziemców o kulturze polskiej. Do 1936 r. wzięli w nich udział cudzoziemcy 23 narodowości. Szwedów było niewielu: w roku 1931 - 1, 1933 - 1, 1935 - 1 (Sprawozdanie $z$ dotychczasowej działalności Ministerstwa Wyznań Religijnych i Oświecenia Publicznego..., bez daty dziennej, luty 1936 r., AAN, MWRiOP, teczka 281, k. 483-485).

18 Do 1936 r. odsetki z „Funduszu Skandynawskiego” w wysokości 12 tys. dolarów służyły do merytorycznego przygotowania kandydata na stanowisko kierownika planowanej katedry. Był nim dr Stanisław Sawicki. Po odbyciu kilkuletnich studiów w krajach skandynawskich (Szwecja, Norwegia, Dania) Sawicki habilitował się $z$ zakresu filologii skandynawskiej na Uniwersytecie 
katedry był prof. Wędkiewicz, który od 1934 r. pracował na Uniwersytecie Warszawskim ${ }^{19}$.

MSZ zainteresowane umacnianiem i rozwijaniem wzajemnych relacji polsko-szwedzkich sprzyjało zawarciu umowy kulturalnej. W połowie lat trzydziestych cele polityki zagranicznej Warszawy i Sztokholmu były zbieżne, m.in. w sprawie reformy Ligi Narodów i jej roli w stosunkach międzynarodowych. Bardzo dobre były relacje J. Becka $z$ szefem szwedzkiej dyplomacji Rickardem Sandlerem, $z$ którym spotykał się w Genewie podczas sesji Rady i Zgromadzenia Ligi Narodów. Beck wychodził z założenia, że dobre stosunki ze Szwecją i pozostałymi państwami skandynawskimi służą umocnieniu roli Polski w stosunkach międzynarodowych ${ }^{20}$. W drugiej połowie lat trzydziestych zauważalny był postęp $\mathrm{w}$ relacjach handlowych, gospodarczych oraz żegludze morskiej między obu krajami $^{21}$.

J. Piłsudskiego w Warszawie w 1937 r. Poprzednio, obok studiów specjalistycznych, prowadził przez półtora roku lektorat języka i literatury polskiej na uniwersytecie w Sztokholmie. W roku akademickim 1939/1940 miał objąc pierwszą w Polsce Katedrę Filologii Skandynawskiej na Uniwersytecie Warszawskim. Wybuch wojny uniemożliwił realizację projektu. Sawicki zginął w czasie powstania warszawskiego (S. Helsztyński, Stanisław Sawicki, „Pamiętnik Literacki” 1946, z. 3-4, s. 369-374).

19 Wędkiewicz postulował organizację studiów skandynawskich w Polsce od 1928 r. Por. S. Wędkiewicz, Przed kongresem historyków w Oslo, „Przegląd Współczesny" 1928, t. XXVI, nr 75 (lipiec), s. 105-123.

$20 \mathrm{~W}$ Warszawie doceniono, że R. Sandler w imieniu rządu szwedzkiego głosował 16 IX 1935 r. za ponownym wyborem Polski do Rady Ligi Narodów. Kandydaturę Polski poparły też pozostałe państwa skandynawskie, o czym J. Beck nie omieszkał wspomnieć w wystapieniu sejmowym 15 V 1936 r. (J. Beck, Przemówienia..., s. 193-194). W „Polskiej Informacji. Politycznej”, półurzędowej agencji publicystycznej prezentującej stanowisko MSZ w sprawach międzynarodowych, pisano, że „przywiązanie” do ideałów Ligi Narodów umiał R. Sandler „połączyć harmonijnie $z$ całokształtem swej polityki zagranicznej, która nacechowana była dużym obiektywizmem i szukała rozwiązań opartych przede wszystkim na potrzebach i interesach jego kraju”. Ta „zbieżność polityki” szwedzkiej $z$ „obecna polityka polska pozwoliła na zbliżenie i rozwój współpracy obu krajów na arenie międzynarodowej” („Polska Informacja Polityczna”, nr 13, Warszawa 27 czerwca 1936 r. Archiwum Instytutu Hoovera, Ambasada Polska w Wielkiej Brytanii, sygn. 800/33/0/-/112 (www.szukajwarchiwach.pl/800\# tab.zasoby).

${ }^{21}$ J. Czechowski, Polsko-szwedzkie relacje ekonomiczne $w$ latach trzydziestych $X X$ wieku $w$ swietle polskich akt $i$ opracowań, „Słupskie Studia Historyczne” 2016, nr 16, s. 103-116. Wyrazem współpracy polsko-szwedzkiej był „Dom Marynarza Szwedzkiego” w Gdyni wybudowany z inicjatywy szwedzkiego konsulatu generalnego na gruncie ofiarowanym przez Ministerstwo Przemysłu 
W wyniku prowadzonych rozmów strona polska i szwedzka uzgodniły, że porozumienie o współpracy kulturalnej zostanie zawarte na szczeblu ministerstw wyznań i oświecenia obu krajów. Z formalnego punktu widzenia nie byłoby konwencją międzypaństwowa, a jedynie protokółem porozumienia między obu ministerstwami. Nie wymagało zatem ratyfikacji i jego postanowienia mogłyby być natychmiast realizowane. Stwarzałoby podstawę i ułatwiałoby organizacjom społecznym oraz osobom prywatnym współpracę na niwie kulturalnej i intelektualnej. $\mathrm{W}$ celu podpisania porozumienia, na zaproszenie strony polskiej, szwedzki minister oświaty i wyznań Artur Engberg i podsekretarz stanu w tymże ministerstwie Börje Knös przybyli do Warszawy 6 czerwca 1935 r. $^{22}$

Wizyta przebiegała w okresie żałoby po śmierci Józefa Piłsudskiego, dlatego nie organizowano „większych przyjęć”. W dniu 7 czerwca Engberg spotkał się $z$ ministrem wyznań religijnych i oświecenia publicznego Wacławem Jędrzejewiczem i premierem Walerym Stawkiem oraz został przyjęty na audiencji przez prezydenta Ignacego Mościckiego ${ }^{23}$. Podpisanie porozumienia o polsko-szwedzkiej współpracy kulturalnej nastąpiło o godz. $13.30 \mathrm{w}$ siedzibie MSZ. Jędrzejewicz i Engberg, w obecności J. Becka, podpisali protokól, w którym wyrazili „wzajemne pragnienie rozwoju i wzmożenia stosunków naukowych, literackich i artystycznych między Polska a Szwecja”. Uzgodniono, że będa „popierać i ułatwiać studia historyczne nad stosunkami między Polską a Szwecją; sprzyjać przekładaniu dzieł literackich naukowych polskich na język szwedzki i przekładaniu dzieł literackich i naukowych szwedzkich na język polski; popierać i ułatwiać wzajemne wizyty profesorów uniwersytetu lub szkół wyższych w celu wygłaszania odczytów lub, ewentualnie specjalnych wykładów". W protokole zapisano również, że

i Handlu Uroczyste poświęcenie placówki odbyło się 12 VI 1936 r. („Codzienna Gazeta Handlowa", 14-15 VI 1936, R. XI, nr 136, s. 5).

22 „Kurier Warszawski”, 8 VI 1935, nr 154, s. 3; Przyjazd szwedzkiego ministra oświaty, „Ilustrowany Kuryer Codzienny”, 8 VI 1935, nr 157, s. 16; Powitanie szwedzkiego ministra oświaty p. Engberga $w$ Warszawie.

${ }^{23} \mathrm{~W}$ dniu 7 VI 1935 r. szwedzcy goście zwiedzili siedmioklasową publiczna szkołe powszechna nr 183 im gen. Józefa Bema i „Państwowy instytut robót ręcznych", złożyli wieniec na Grobie Nieznanego Żołnierza oraz wpisali się do księgi kondolencyjnej w Belwederze wyłożonej w związku ze śmiercią J. Piłsudskiego (Min. Engberg w Warszawie, „Kurier Warszawski”, 8 VI 1935, nr 156, s. 3; E.Z [Eugeniusz Zdrojewski], Pobyt $w$ Polsce szwedzkiego ministra oświaty, „Oświata i Wychowanie” 1935, R. VI, z. 7-9, s. 449). 
w celu „skoordynowania zarządzeń, zmierzających do rozwinięcia stosunków intelektualnych między obydwoma Krajami, zamierzaja oni sprzyjać utworzeniu w każdym Państwie komitetu, który będzie miał powierzone sobie to zadanie. Komitety te będa mogły bezpośrednio korespondować między sobą"24.

Tego samego dnia o godz. 17.30 odbyło się otwarcie „Biblioteki Szwedzkiej” na ul. Królewskiej 3 z udziałem Engberga i Knösa. Uroczystość otworzył B. Calleman, lektor języka szwedzkiego na Uniwersytecie Warszawskim, który obją kierownictwo nowo otwartej placówki. W okolicznościowym wystapieniu podkreślił coraz większe zainteresowanie Polski „problemami i życiem kulturalnym Szwecji”. Wieczorem szwedzcy goście w towarzystwie ministra W. Jędrzejewicza i ambasadora Erika Bohemana udali się do Krakowa, a 8 czerwca wieczorem do Poznania, skąd następnego dnia odlecieli do Szwecji ${ }^{25}$.

Przewidziane protokółem utworzenie komitetu nastąpiło w Szwecji dopiero kilka miesięcy po jego podpisaniu. Komitet powołany przez ministra Engberga zebrał się 25 października 1935 r. i 19 lutego 1936 r. Jego przewodniczącym został B. Knös, wspomniany podsekretarz stanu w Ministerstwie Oświaty i Wyznań, z wykształcenia doktor filologii greckiej, tłumacz literatury nowogreckiej. W skład komitetu weszli: Per Sigurd Agrell - profesor slawistyki na uniwersytecie w Lund, który „po polsku mówił niemal tak biegle jak Polak"26; H.KH. Almquist - dyrektor archiwów państwowych; płk A.G. von Arbin - przewodniczący Towarzystwa Szwedzko-Polskiego w Sztokholmie; baron O.R. Cederström; Isak G.A. Collijn - bibliograf i wydawca, dyrektor Biblioteki Narodowej; G.O.I. Gunnarsson - slawista, wykładowca na uniwersytecie w Uppsali (sekretarz komitetu) oraz Marika S.A. Stiernstedt-Nordström - autorka nowel i powieści. Komitet uznał, że jednym $z$ elementów polsko-szwedzkiej współpracy intelektualnej powinno być zamieszczanie w czasopismach literackich obu krajów, przynajmniej raz w roku,

${ }^{24}$ Protokół został sporządzony w j. polskim i francuskim. „Protokół o współpracy intelektualnej między Polska a Szwecją 7 czerwca 1935 r. podpisany w Warszawie niepublikowany - do dyspozycji Min. Oświaty”. Ogłoszony w: „Dziennik Urzędowy MWRiOP z 1936 r.”, nr 1, poz. 9 (AAN, MWRiOP, teczka 281, k. 419-420).

${ }^{25}$ O przebiegu wizyty w Krakowie i Poznaniu: E.Z (Eugeniusz Zdrojewski), Pobyt w Polsce szwedzkiego ministra oświaty, "Oświata i Wychowanie” 1935, R. V, z. 6, s. 449.

${ }^{26}$ Z. Łakociński, Per Sigurd Agrell, „Przegląd Współczesny” 1937, t. LXII, nr 183, s. $118-121$. 
przeglądu najwybitniejszych dzieł literackich drugiego państwa. Wykaz osiągnięć literatury polskiej byłby zamieszczany na łamach „Bonniers Litterāre Magasin”. Podobny przegląd prac historycznych i badań naukowych $z$ dziedziny historii znalazłby się, ze strony szwedzkiej, w periodyku „Historisk Tidskrift”. Komitet opowiedział się za ułatwianiem otrzymywania paszportów „ulgowych” przez uczonych polskich udajacych się do Szwecji ${ }^{27}$.

Jeszcze później został powołany Komitet Polsko-Szwedzkiej Współpracy Kulturalnej przy MWRiOP. Jesienią 1935 r. w Polsce nastapiły wydarzenia polityczne, które skutkowały m.in. zmiana rzacdu. Wybory parlamentarne przewidziane na 8 (Sejm) i 15 (Senat) września 1935 r. otwierały okres funkcjonowania władz państwowych według zasad określonych w konstytucji z 23 kwietnia 1935 r. Zgodnie $z$ obyczajem po wyborach W. Sławek podał swój rząd do dymisji, która została przyjęta przez prezydenta I. Mościckiego, skonfliktowanego $\mathrm{z}$ premierem. Formalna dymisja gabinetu nastąiła 12 października 1935 r. Następnego dnia został powołany gabinet Mariana Zyndrama-Kościałkowskiego, w którym nie obsadzono stanowisko ministra wyznań religijnych i oświecenia publicznego. Funkcje „kierownika” do 5 grudnia 1935 r. pełnił Konstanty Chyliński - dotychczasowy podsekretarz stanu w tym ministerstwie, historyk starożytności na Uniwersytecie Jana Kazimierza we Lwowie. Nowym szefem resortu został prof. Wojciech Świętosławski - chemik i biofizyk o międzynarodowej renomie, były rektor Politechniki Warszawskiej (1928-1929).

Dopiero nowy minister powołał przewidziany protokołem z 7 czerwca 1935 r. Komitet Polsko-Szwedzkiej Współpracy Kulturalnej. Przewodniczaccym komitetu został nowo mianowany wiceminister MWRiOP, płk Jerzy Ferek-Błeszyński, do 5 grudnia 1935 r. attaché wojskowy w Paryżu. W skład komitetu weszli: Włodzimierz Antoniewicz - archeolog, profesor Uniwersytetu Warszawskiego; Stanisław Jan Przyłęcki - biochemik i fizjolog, profesor Uniwersytetu Warszawskiego; Czesław Maciej Witoszyński - profesor aerodynamiki Politechniki Warszawskiej; prof. Stanisław Wędkiewicz; doc. dr Wanda Moszczeńska - mediewistka, nauczycielka szkół średnich i wykładowca na Uniwersytecie Warszawskim; Witold

27 AAN, MWRiOP, teczka 281, Legation de Suede. Note verbale, Varsovie, le 7 octobre 1936, k. 473-474; E.Z. (Eugeniusz Zdrojewski), Komitety polsko-szwedzkiej wspótpracy intelektualnej, „Oświata i Wychowanie” 1936, R. VII, z. 4, s. 320-321. 
Suchodolski - Naczelny Dyrektor Archiwów Państwowych przy MWRiOP; Bolesław Kielski - ministerialny wizytator szkół w MWRiOP; dr Józef Borowik - ichtiolog, od 1930 r. dyrektor Instytutu Bałtyckiego w Toruniu; Kazimierz Wierzyński - poeta i prozaik. Ekspertami MWRiOP byli: radca Leopold Białobrzeski i radca Kazimierz Wóycicki - ministerialny wizytator i referent do spraw literatury i teatrów. MSZ reprezentował dr Jan Starzewski - wicedyrektor Departamentu Politycznego. Doktor Stanisław Sawicki, skandynawista, został sekretarzem komitetu ${ }^{28}$.

Według przygotowanego prawdopodobnie przez B. Kielskiego projektu regulaminu zadaniem komitetu było „organizowanie stałej współpracy w dziedzinie naukowej, literackiej i artystycznej między Polska a Szwecja”. Komitet miał pozostawać w „ścisłej współpracy i współdziałaniu z Komitetem w Sztokholmie" oraz utrzymywać „bezpośredni kontakt” i nawiązywać współpracę $z$ Instytutem Bałtyckim w Toruniu, Stowarzyszeniem Polsko-Szwedzkim i innymi organizacjami społecznymi. Komitet miał się zbierać nie rzadziej niż dwa razy w roku na zaproszenie przewodniczącego, który ustalał przedmiot i porządek obrad. Członkowie komitetu, w zakresie powierzonych im zadań, mogli powoływać do współpracy podkomitety, którym przewodniczyli. Komitet miał prowadzić korespondencję $z$,władzami urzędowymi szwedzkimi” za pośrednictwem MWRiOP lub MSZ w „zależności od jej przedmiotu i treści”. Bezpośrednia korespondencja „Komitetu Warszawskiego” $z$ komitetem w Sztokholmie miała być prowadzona w języku francuskim. Wyniki prac komitetu i podkomitetów oraz sprawozdania $z$ działalności w poszczególnych dziedzinach stosunków kulturalnych polsko-szwedzkich miały być przedstawiane MWRiOP oraz MSZ. Oba ministerstwa miały finansować „postulaty i potrzeby” komitetu „W miarę możliwości budżetowych"29.

Dnia 18 lutego 1936 r., podczas pierwszego posiedzenia komitetu pod przewodnictwem wiceministra J. Ferek-Błeszyńskiego, referentem był B. Kielski, który przedstawił scharakteryzowany wyżej projekt regulaminu komitetu, omówił dotychczasową działalność MWRiOP w zakresie stosunków kulturalnych ze Szwecja

${ }^{28}$ Skład osobowy Polsko-Szwedzkiego Komitetu Współpracy Kulturalnej, AAN, MWRiOP, teczka 281, k. 478.

29 Regulamin Komitetu Polsko-Szwedzkiego Współpracy Kulturalnej przy Ministerstwie Wyznań Religijnych i Oświecenia Publicznego, AAN, MWRiOP, teczka 281, k. 452-453. 
i zaprezentował planowany zakres prac. Zebrani przyjęli regulamin $z$ niewielkimi poprawkami, ustalając oficjalna nazwę powołanego organu jako Polsko-Szwedzki Komitet Współpracy Kulturalnej, w skrócie: „Komitet Warszawski”. Podkreślono autonomiczny charakter prac komitetu i planowanych podkomitetów oraz opowiedziano się za wprowadzeniem języka szwedzkiego, obok polskiego i francuskiego, jako języka korespondencji. Zgodnie $z$ sugestia J. Starzewskiego, delegata MSZ, uznano, że komitet mógłby zapraszać przedstawiciela szwedzkiego „w osobie sekretarza Poselstwa szwedzkiego w Warszawie" na roczne posiedzenia sprawozdawcze bądź dotyczące kwestii, w których „współdziałanie strony szwedzkiej byłoby pożądane". Taka współpraca ze strony poselstwa szwedzkiego „stworzyłaby korzystny precedens dla analogicznego współdziałania przedstawiciela naszego Poselstwa $z$ komitetem szwedzkim"30.

Kielski zreferował „obszerny projekt działalności Komitetu obejmujacy sprawy współpracy w zakresie nauki, literatury i sztuki oraz popularyzacji znajomości języka i krajów odnośnych". W zakresie nauki komitet miał inicjować i organizować badania historyczne, folklorystyczne, geograficzne, przyrodnicze, techniczne oraz sprawy zwiazane $z$ organizacja szkolnictwa i oświaty. Kolejnym zadaniem było popieranie działalności instytucji naukowych i ich rozbudowy (stacja morska na Helu, Instytut Bałtycki), popieranie przekładów dzieł naukowych i odpowiednich wystaw (etnologicznych, książki). Komitet miał ułatwiać kontakt i współpracę uczonych obu krajów, popierać udział specjalistów polskich w „konferencjach i zjazdach bałtyckich", wymianę profesorów oraz studentów-stypendystów w celu prowadzenia prac badawczych i „praktyk wymiennych dla studentów wyższych zakładów technicznych”. Jego zadaniem było również tworzenie katedr i lektoratów filologii polskiej w Szwecji, „względnie skandynawskiej w Polsce”.

Współpraca w zakresie literatury i sztuki miała polegać na popieraniu przekładów utworów literackich, wprowadzeniu „(kilku) sztuk polskich na sceny szwedzkie i wzajemne", wymianie sztuk plastycznych, koncertów filharmonicznych, ułatwianiu kontaktu i współpracy literatów i artystów polskich i szwedzkich oraz stosownych instytucji. Przewidziano także współpracę w zakresie „popularyzacji

${ }^{30}$ Pismo wicedyrektora Departamentu Politycznego MSZ dra Jana Starzewskiego z 19 lutego 1936 r., AAN, MWRiOP, teczka 281, k. 459. Sugestię Starzewskiego przyjęto podczas spotkania 18 II i zapisano w regulaminie komitetu. 
i propagandy znajomości języka i krajów odnośnych”. Komitet miał zadbać o „odpowiednie uwzględnianie tych wiadomości w programach i podręcznikach szkolnych", opracowanie popularnych słowników i gramatyk, wydawnictw popularnych i artykułów „propagandowych”, urządzenie odczytów, audycji radiowych oraz organizowanie kontaktu, wycieczek, wymiany i korespondencji nauczycielstwa i młodzieży. Kielski proponował, aby do realizacji tego szerokiego programu działania powołać pięć podkomitetów: nauk humanistycznych, nauk przyrodniczo-technicznych, literatury i teatru, sztuk plastycznych i muzycznych, wydawnictw naukowo-popularnych oraz imprez propagandowych ${ }^{31}$.

Listem z 22 lutego 1936 r. (w języku francuskim) J. Ferek-Błeszyński powiadomił B. Knösa, że minister Świętosławski powołał komitet w sprawie „stosunków intelektualnych” między Polską i Szwecja przewidziany protokółem z 7 czerwca 1935 r., który zebrał się po raz pierwszy 18 lutego. Pismo zawierało wykaz osób stanowiących komitet oraz informacje o odbytym pierwszym posiedzeniu i podjętych decyzjach. Ferek-Błeszyński uznał za stosowne wyjaśnienie powodów zwłoki w powołaniu polskiego komitetu. Napisał, że „poważne opóźnienie w organizacji komitetu” było spowodowane zmianami personalnymi na stanowisku ministra i podsekretarza stanu w MWRiOP. Zapewnił Knösa, że nowe kierownictwo ministerstwa wyraża wolę „zacieśnienia więzi kulturalnych z Pana pięknym krajem"32.

${ }^{31}$ Proponowany skład osobowy: 1. Podkomitet nauk humanistycznych: prof. S. Wędkiewicz, Włodzimierz Antoniewicz, Zygmunt Łempicki, dr Stanisław Sawicki, dr Wanda Moszczeńska, dr J. Borowik, Witold Suchodolski, radca MWRiOP L. Białobrzeski; 2. Podkomitet nauk przyrodniczo-technicznych: prof. Stanisław Przyłęski, C.M. Witoszyński, dr J. Borowik, radca MWRiOP L. Białobrzeski; 3. Podkomitet literatury i teatru: literat Kazimierz Wierzyński, Kazimierz Wóycicki - radca MWRiOP; 4. Podkomitet sztuk plastycznych i muzycznych: historyk sztuki, generalny konserwator zabytków Jerzy Remer, radca K. Wóycicki, 5. Podkomitet wydawnictw naukowo-popularnych: J. Borowik, dr S. Sawicki. Przewodniczacy podkomitetów mogli dobierać nowych członków. Podkomitety miały współpracować z takimi „instytucjami ogniskowymi”, jak: PKMWI, Instytut Bałtycki w Toruniu, Towarzystwo Krzewienia Sztuki Polskiej wśród Obcych, Towarzystwo Polsko-Szwedzkie, PENclub, Muzeum Oświaty i Wychowania, towarzystwa naukowe (Protokół $z$ pierwszego posiedzenia Polsko-szwedzkiego Komitetu współpracy kulturalnej, odbytego dn. 18 lutego 1936 w MWRiOP, AAN, MWRiOP, teczka 281, k. 479-482; protokółował dr S. Sawicki).

${ }^{32}$ Pismo J. Ferek-Błeszyńskiego do B. Knösa w języku francuskim 22 lutego 1936 r., 22 lutego 1936 r., AAN, MWRiOP, teczka 281, k. 461-462. 
Kolejne zebranie komitetu, zgodnie $z$ decyzja podjęta podczas pierwszego spotkania, odbyło się 3 marca. Dyskusja dotyczyła programu działania komitetu i podkomitetów oraz ich składu. Wierzyński zreferował sprawę podkomitetu literatury i teatru, zgłaszając wniosek o jego połączenie $z$ podkomitetem nauk humanistycznych. Po dyskusji, w której podkreślano „znaczenie kontaktów osobistych”, postanowiono utworzyć podkomitet "humanistyczno-artystyczny” pod przewodnictwem Wędkiewicza. Ostatecznie zdecydowano o powołaniu trzech, a nie pięciu - jak pierwotnie proponował B. Kielski - podkomitetów: nauk humanistycznych, literatury i sztuk pięknych pod przewodnictwem prof. S. Wędkiewicza; nauk przyrodniczych pod kierownictwem prof. S. Przyłęckiego oraz wydawniczego pod przewodnictwem J. Borowika. Wynikało to $z$ ustalonej kolejności spraw uznanych za najpilniejsze: przygotowania wydawnictw naukowo-popularnych, opracowania słowniczków ewentualnie gramatyk, przygotowania dyrektyw dla lektoratów polskich w Szwecji; współpracy w dziedzinie „badań przyrodniczych” dotyczacych Morza Bałtyckiego i jego rejonu, organizacji pracy nad przekładami dzieł literackich oraz rozpraw $z$ zakresu nauk humanistycznych i przyrodniczo-technicznych. W dalszej kolejności miano zorganizować badania historyczne stosunków polsko-szwedzkich, „sprawdzenie i uzupełnienie podręczników szwedzkich w zakresie rzeczy polskich", kontakty oraz wymianę profesorów i studentów, zarówno nauk humanistycznych, jak i przyrodniczo-technicznych ${ }^{33}$. Zgodnie $z$ autonomicznym charakterem funkcjonowania podkomitetów ich przewodniczacy mieli prawo powoływania członków bądź zapraszania doraźnych współpracowników bez akceptacji ze strony przewodniczącego komitetu. Składy podkomitetów mogły ulegać zmianom w zależności od specyfiki i zakresu podejmowanych działań ${ }^{34}$.

Dnia 24 marca 1936 r., z inicjatywy J. Borowika, zebrał się podkomitet wydawniczo-propagandowy w Polskim Instytucie Współpracy $z$ Zagranica (PIWZ) w Warszawie. W jego skład weszli: dr Karol Bertoni - prawnik, były dyrektor Departamentu Prawno-Administracyjnego MSZ, profesor Studium Dyplomatycznego Uniwersytetu Jana Kazimierza we Lwowie; Jan Dębski - dyrektor biura Ligi Morskiej i Kolonialnej, wydawca kwartalnika „Sprawy morskie i kolonialne"; dr Stanisław Kauzik; Mieczysław Fularski

${ }^{33}$ Główne punkty programu działalności Komitetu polsko-szwedzkiego, bez daty dziennej, luty 1936 r., AAN, MWRiOP, teczka 281, k. 488-491; E.Z., op. cit., s. 321.

${ }^{34}$ Pismo B. Kielskiego z 2 kwietnia 1936 r., AAN, MWRiOP, teczka 281, k. 503. 
- podróżnik i reportażysta; dr Wanda Moszczeńska; Leonard Możdżeński - Dyrektor Departamentu Morskiego w Ministerstwie Przemysłu i Handlu; Roman Starzyński - dyrektor Spółki Akcyjnej Polskie Radio; dr Aleksy Wdziękoński - zastępca naczelnika Wydziału Prasowego MSZ; Zbigniew Zaniewicki - prozaik i poeta, sekretarz PKMWI od 1929 r. oraz Jerzy Życki - dyrektor PIWZ ${ }^{35}$.

Miesiąc później Borowik przesłał do Kielskiego pismo zawierające wnioski, które skrystalizowały się na zebraniu podkomitetu wydawniczo-propagandowego oraz „w wyniku późniejszych rozmów i korespondencji z zainteresowanymi instytucjami i osobami”. Postanowiono uzgodnić i usystematyzować akcję odczytową towarzystw polsko-szwedzkich w Polsce i szwedzko-polskich w Szwecji $z$ tym, żeby poszczególne wykłady były drukowane, „tworząc zeszyty szerzej pomyślanej jednolitej serii wydawnictw, wychodzacych pod auspicjami komitetów rządowych zbliżenia polsko-szwedzkiego a wydawanych przez Instytuty Batyckie w Polsce i Szwecji”. Kolejnym przedsięwzięciem miało być uruchomienie w obu krajach serii wydawnictw naukowo-popularnych $z$ zakresu historii, geografii i kultury oraz organizowanie przez towarzystwa krajoznawcze i turystyczne „okrężnych wystaw poświęconych krajobrazowi i sztuce ludowej" prezentowanych w głównych ośrodkach kulturalnych Polski i Szwecji. Uznano, że PKMWI oraz jej szwedzka odpowiedniczka podjęłyby się zbadania podręczników historii i geografii oraz uzupełnienia ich „materiałem ułatwiajaccym poznanie innego kraju". To samo mogłoby dotyczyć wydawnictw encyklopedycznych. PKMWI zajęłaby się również poparciem akcji wymiany korespondencji szkolnej między młodzieżą obu krajów i organizowaniem „wycieczek przyjaźni” $z$ obu krajów na zasadach wzajemności. Do akcji tej mogłoby właczyć się Towarzystwo Krajoznawcze oraz „Orbis”. Planowano wydawanie przez Instytut Bałtycki biuletynów prasowych, które by podawały ważniejsze wiadomości z życia kulturalnego i naukowego i służyły w rozprowadzaniu tych wiadomości w prasie oraz za pośrednictwem radia, „budzac w ten sposób głębsze zainteresowanie sprawami innego kraju i co ważniejsze - przyczyniając się do zrozumienia istoty zjawisk, zachodzących w życiu”. Borowik zaznaczył, że „wszystkie te wnioski wtedy tylko zostana zrealizowane, o ile zapatrywania nasze co do użyteczności tych poczynań zaakceptuje Komitet pełny i o ile będzie zapewniona

${ }^{35}$ Pismo J. Borowika do B. Kielskiego z 24 marca 1936 r., AAN, MWRiOP, teczka 281, k. 500 . 
wzajemność w wyniku podobnego stanowiska ze strony komitetu szwedzkiego. Czyli - droga jeszcze jest bardzo daleka"36.

Kierowany przez Borowika podkomitet sceptycznie odniósł się do proponowanych przez komitet sztokholmski form współpracy, wyrażając „poważne wątpliwości co do ich praktycznego znaczenia i celowości”. Uznano, że „skróty czy omówienia dzieł literackich dla szerszej publiczności miałyby tym mniejsze znaczenie im bardziej doskonałe byłyby to dzieła, które wymagaja każde obszerniejszego streszczenia i interpretacji przez poważniejszych krytyków, przy tym raczej ze stanowiska czytelnika szwedzkiego". Wyrażono również pogląd, że opracowywanie referatów „dotyczących dzieł historycznych i zbiorów archiwalnych - wymaga uzgodnienia $z$ poczynaniami prowadzonymi w tej dziedzinie w obu krajach $z$ ramienia Komitetu Międzynarodowego Historyków i Komisji Międzynarodowej Współpracy Intelektualnej"37.

Podkomitet nauk humanistycznych, literatury i sztuk pięknych pod kierunkiem Wędkiewicza zamierzał nadal informować polskiego czytelnika o życiu naukowym i literackim Szwecji na łamach „Przeglądu Współczesnego”. Sprawozdania z literatury historycznej szwedzkiej planowano publikować na łamach „Kwartalnika Historycznego", którego redaktor Kazimierz Tyszkowski, kustosz Ossolineum we Lwowie, interesował się zagadnieniami relacji szwedzko-polskich w XVI i XVII stuleciu ${ }^{38}$. Były to zamierzenia adekwatne do poczynań komitetu sztokholmskiego, który uzyskał zgodę czasopism „Bonniers Litterära Magasin” (red. M.G. Svensson)

${ }^{36}$ Pismo J. Borowika do B. Kielskiego 27 kwietnia 1936 r., AAN, MWRiOP, teczka 281, k. 506-507.

37 Obecny stan realizacji postanowień zawartych w protokóle dotyczacym współpracy kulturalnej polsko-szwedzkiej. Notatka dla P. Ministra (odpis, bez daty dziennej), AAN, MWRiOP, teczka 281, k. 538-543.

${ }^{38}$ Pismo S. Wędkiewicza z 25 marca 1936 r., AAN, MWRiOP, teczka 281, k. 504. Podkomitet nauk humanistycznych, literatury i sztuk pięknych tworzyli: prof. Włodzimierz Antoniewicz - rektor Uniwersytetu J. Piłsudskiego; Zygmunt Łempicki - prof. UW; Stanisław Wędkiewicz - prof. UW; dr Stanisław Sawicki - docent UW; dr Wanda Moszczyńska - docent UW; Józef Borowik - dyr. Archiwów Państwowych przy MWRiOP; Witold Suchodolski; radca L. Białobrzeski. Kielski odpisał 2 IV, z upoważnienia przewodniczacego komitetu, że przewodniczacy „przyją do wiadomości" treść listu i wyraził nadzieję, że Podkomitet rozważy przygotowanie syntetycznych sprawozdań $z$ ruchu naukowo-literackiego w Polsce i literatury historycznej polskiej, przeznaczonych do czasopism szwedzkich. Przypomniał, że Podkomitet podją się opracowania programu działalności i przedstawienia go na posiedzeniu „Komitetu Warszawskiego", planowanego w połowie maja br.” (Pismo B. Kielskiego z 2 kwietnia 1936 r., AAN, MWRiOP, teczka 281, k. 502). 
i „Historisk Tidskrift” na zamieszczenie sprawozdań o dziełach z zakresu literatury i nauki historycznej polskiej39.

W pierwszej dekadzie maja $1936 \mathrm{r}$. była planowana wizyta ministra Świętosławskiego w Szwecji. Oprócz charakteru „kurtuazyjno-reprezentacyjnego" program wizyty miał się wpisywać w całokształt współpracy intelektualnej między obu krajami. Dla ministra została przygotowana notatka na temat stanu realizacji, a faktycznie przedstawionych wyżej zamierzeń polskiego komitetu w sprawie współpracy kulturalnej ze Szwecją. W skład delegacji weszli: B. Kielski, zajmujący się na co dzień pracami komitetu w MWRiOP, i dr Aleksander Zmaczyński, adiunkt w Zakładzie Chemii Fizycznej Politechniki Warszawskiej, współpracujacy badawczo z prof. Świętosławskim, członek Podkomitetu przyrodniczego ${ }^{40}$. W Szwecji miał dołączyć do delegacji sekretarz „Komitetu Warszawskiego”, dr Stanisław Sawicki (przebywał wówczas w Kopenhadze). Jak pisał B. Kielski, chodziło o nawiązanie „osobistego kontaktu między niektórymi przynajmniej członkami obu komitetów”, co mogło mieć „praktyczne znaczenie, ułatwiając porozumienie się na przyszłość"

Wizyta polskiej delegacji MWRiOP (6-9 maja 1936 r.) stwarzała okazję do kontaktów ze środowiskiem naukowym szwedzkim. Obok oficjalnego spotkania ministra Świętosławskiego $z$ ministrem Engbergiem i podsekretarzem stanu B. Knösem, przewodniczącym komitetu szwedzkiego, oraz audiencji u króla Gustawa V, w Poselstwie $\mathrm{RP}$ w Sztokholmie zorganizowano przyjęcie, w którym uczestniczyła „elita intelektualna stolicy szwedzkiej”. W Instytucie Biochemicznym w Sztokholmie prof. Świętosławski wygłosił odczyt na temat

39 Obecny stan realizacji postanowień zawartych w protokóle dotyczącym współpracy kulturalnej polsko-szwedzkiej. Notatka dla P. Ministra (odpis, bez daty dziennej), AAN, MWRiOP, teczka 281, k. 540.

40 Zmaczyński został członkiem Podkomitetu przyrodniczego, a zarazem „Komitetu Warszawskiego” w miejsce prof. Witoszyńskiego, który zrezygnował z udziału w pracach komitetu. Dnia 2 V prof. Przyłęcki, przewodniczący komitetu nauk przyrodniczych, wystapił do B. Kielskiego $z$ wnioskiem o nominację Zmaczyńskiego na członka Komitetu. Wniosek skierowany do ministra MWRiOP Świętosławskiego zyskał jego akceptację, o czym W. Przybyłowicz, Dyrektor Biura Personalnego w MWRiOP, poinformował J. Ferek-Błeszyńskiego 26 V 1936 r. (AAN, MWRiOP, teczka 281, k. 509).

${ }^{41}$ Obecny stan realizacji postanowień zawartych w protokóle dotyczącym współpracy kulturalnej polsko-szwedzkiej. Notatka dla P. Ministra (odpis, bez daty dziennej), AAN, MWRiOP, teczka 281, k. 538-543; B.K. (Bolesław Kielski), Podróż Ministra WRiOP. Prof. Dr. W. Świętosławskiego do Szwecji, „Oświata i Wychowanie” 1936, R. VIII, z. 6, s. 485-486. 
jego badań fizyko-chemicznych i zademonstrował skonstruowany przez siebie aparat do badania czystości cieczy. Odczyt został uzupełniony przez dra Zmaczyńskiego sprawozdaniem $z$ badań przeprowadzonych przez niego pod kierunkiem prof. Świętosławskiego. Program wizyty dopełniło zwiedzanie zakładów naukowych, muzeów i placówek oświatowych w Sztokholmie i Uppsali. Dnia 8 maja, podczas obiadu wydanego na cześć ministra Świętosławskiego, w którym uczestniczyli rektorzy i profesorowie szwedzkich uczelni, Engberg wygłosił przemówienie, podkreślając znacznie polsko-szwedzkich stosunków intelektualnych. Powiedział m.in., że obok stosunków dyplomatycznych istnieją „równie doniosłe między uczonymi, literatami i artystami”. „W dzisiejszej skomplikowanej sytuacji międzynarodowej - mówił Engberg - zbliżenie kulturalne jakie nawiązaliśmy, wychodzi poza ramy swych bezpośrednich zadań, wywierając dobroczynny wpływ na sferę czystej polityki" ${ }^{2}$.

Tymczasem sprawy formalne i organizacyjne utrudniały bądź powstrzymywały realizację niektórych zamierzeń współpracy kulturalnej między obu krajami. Wiosna 1936 r. komitet sztokholmski wystapił z inicjatywa „wymiany wzajemnej dzieł muzyki polskiej i szwedzkiej”. Propozycje taka zgłosił Kurt Atterberg, kompozytor i dyrygent, przewodniczący stowarzyszenia kompozytorów szwedzkich. Zwrócił uwage, że Szwecja miała „bardzo często wielką przyjemność” poznawania dzieł polskiej „kultury muzycznej” (koncerty pianisty Mieczysława Münza i orkiestry pod dyrekcją Tadeusza Mazurkiewicza, kompozycje Ludomira Różyckiego). Atterberg proponował, aby również współczesna muzyka szwedzka była w Polsce szerzej popularyzowana w programach radiowych ${ }^{43}$.

Ferek-Błeszyński poparł szwedzka propozycję. Pismem z 28 kwietnia 1936 r. zwrócił się do dyrekcji Polskiego Radia „z prośbą o zorganizowanie koncertów szwedzkich tytułem wzajemności za koncerty polskie, zorganizowane przez Radio szwedzkie". Ferek-Błeszyński zaznaczył, że MWRiOP „przywiązuje dużą wagę do sprawy zadośćuczynienia prośbie komitetu szwedzkiego i prośbę też góry jak najsilniej popiera, wyrażając nadzieję, że dyrekcja polskiego radia, zechce wstawić do swego programu koncerty poświęcone muzyce szwedzkiej i przynajmniej jeden $z$ tych koncertów zrealizować w możliwie

${ }^{42} Z$ pobytu min. Świętosławskiego w Szwecji, „Ilustrowany Kuryer Codzienny”, 10 V 1936, nr 129, s. 17.

${ }^{43}$ Pismo B. Knösa do przewoźniczego polskiego komitetu w jęz. francuskim, 31 marca 1936 r., AAN, MWRiOP, teczka 281, k. 536-537. 
najkrótszym terminie $z$ zaznaczeniem, iż wynika on $z$ tendencji wzajemnej wymiany dóbr kulturalnych między Polska a Szwecja"44.

Z odpowiedzi, jakie do MWRiOP nadesłała dyrekcja Polskiego Radia, wynikało, że od wielu lat w dniu szwedzkiego święta narodowego (6 czerwca) organizowano koncerty poświęcone muzyce szwedzkiej. Poza tym uwzględniano również utwory szwedzkie w „programach zwykłych audycji”. Dnia 6 października 1935 r. Polskie Radio zaproponowało radiofonii szwedzkiej „regularna wymianę artystów" na wzór wymiany, jaka nawiązano z Niemcami, Austria, Łotwa, Estonia, Danią i Wegrami. Jednak strona szwedzka nie udzieliła odpowiedzi ${ }^{45}$. Dochodziło więc jedynie do „sporadycznego, nader rzadkiego udziału artystów polskich lub szwedzkich w audycjach radiowych". Polskie Radio deklarowało uwzględnianie „w miarę możności” materiału muzyki ludowej i współczesnej, jaki otrzymało od radiofonii szwedzkiej ${ }^{46}$.

Do października 1936 r. radiofonia szwedzka nie odpowiedziała na propozycję Polskiego Radia o „regularnej wymianie” artystów. Knös nie zamierzał w tej sprawie interweniować. Poinformował „Komitet Warszawski”, że polska propozycja „regularnej wymiany” artystów i programów będzie „trudna do zorganizowania”, dlatego opowiedział się za wymiana „indywidualna i zależnie od okoliczności” 47.

W październiku 1936 r. nastąpiła zmiana na stanowisku przewodniczącego „Komitetu Warszawskiego”. Ferek-Błeszyński zrezygnował $z$ pełnienia tej funkcji, a jego miejsce zajął Józef Ujejski

${ }^{44}$ Pismo Błeszyńskiego do dyrekcji Polskiego Radia z 28 kwietnia 1936 r., AAN, MWRiOP, teczka 281, k. 535.

${ }^{45}$ Pismo wicedyrektora programowego Polskiego Radia, 9 maja 1936 r., AAN, MWRiOP, teczka 281, k. 548.

46 Pismo sekretarza generalnego Polskiego Radia, inż. Zygmunta Karaffa-Kraueterkrafta do B. Kielskiego z 31 sierpnia 1936 r., AAN, MWRiOP, teczka 281, k. 560. Sekretarz generalny pisał, że „Polskie radio nie posiada $z$ radiofonia szwedzka specjalnej umowy o wymianie programów i artystów". Polskie Radio otrzymało „dość obfity materiał muzyki ludowej i współczesnej szwedzkiej i w miarę możności będzie uwzględniało go w swych audycjach. Przesłaliśmy również w swoim czasie szereg nut muzyki współczesnej ludowej polskiej”.

${ }^{47}$ Pismo Knösa do Ujejskiego z 28 października 1936 r., AAN, MWRiOP, teczka 281, k. 566-56. Roman Starzyński, dyrektor Spółki Akcyjnej Polskie Radio, pisał do MWRiOP 12 XII 1936 r., że „sprawa wymiany programów i artystów między radiofonia polską i szwedzką ciągnie się od dn. 31 III 1936 r. Pomimo ustnych konferencji, jakie podczas zjazdów Międzynarodowej Unii Radiofonicznej odbyli ze soba przedstawiciele PR z przedstawicielami radiofonii szwedzkiej nie udało się nam uzyskać dotychczas żadnych pozytywnych rezultatów" (AAN, teczka 281, k. 562). 
- podsekretarz stanu w MWRiOP, profesor literatury na Uniwersytecie Warszawskim i jego były rektor (1932-1933). W zakres powierzonych mu obowiązków wchodziły sprawy międzynarodowych porozumień intelektualnych Polski, w tym komitetu współpracy kulturalnej ze Szwecją. Pismem z 17 października 1936 r. Ferek-Błeszyński podziękował Börje Knösowi za dotychczasowa „cenna współpracę" i wyraził "głęboka nadzieję", że $z$ nowym przewodniczacym „Komitetu Warszawskiego” będzie współpracował z taka sama jak do tej pory "gorliwością"48.

Dwa dni później minister Świętosławski poinformował Artura Engberga o zmianie na stanowisku przewodniczącego polskiego komitetu. Podkreślił, że nie spowoduje to żadnych trudności w „sprawie naszej współpracy polsko-szwedzkiej”. Nadmienił, że zachowuje jak najlepsze wspomnienia o wizycie w Sztokholmie w maju 1936 r. i „niezwykłej gościnności”, jakiej doznał w Szwecji ${ }^{49}$.

Nasuwa się uwaga, że oficjalnie, na szczeblu rządowym, zarówno w Warszawie, jak i w Sztokholmie przywiazywano znaczenie nie tyle do faktycznej, co do formalnej strony polsko-szwedzkiego porozumienia o współpracy kulturalnej. Protokół podpisany 7 czerwca 1935 r. traktowano jako element pozytywnego obrazu relacji dwustronnych. Szwedzki minister spraw zagranicznych Rickard Sandler wyraził to, będac $z$ oficjalna wizyta w Warszawie w sierpniu 1937 r. Wygłaszając toast podczas obiadu wydanego przez J. Becka 25 sierpnia powiedział, że w całokształcie pomyślnie rozwijających się stosunków polsko-szwedzkich nastąpiło „godne uwagi ożywienie" w dziadzinie kulturalnej wskutek podpisanego dwa lata temu protokółowi o współpracy intelektualnej ${ }^{50}$.

Funkcjonowanie komitetu w następnych latach wykracza poza temat artykułu. Wspomnieć jedynie należy, że „Komitet Warszawski”, mimo ambitnych planów MWRiOP z wiosny 1936 r., nie przyczynił się do zasadniczego rozwoju polsko-szwedzkich stosunków kulturalnych. Skład osobowy komitetu ulegal zmianom, m.in. nieoczekiwanie 8 lipca 1937 r. zmarł jego przewodniczacy. wiceminister J. Ujejski. Udział w pracach komitetu był dobrowolny, różny był stopień zaangażowania jego członków. Jedynie podkomitet

${ }^{48}$ Pismo Jerzego Ferek-Błeszyńskiego do Knösa, 27 X 1936 r., AAN, MWRiOP, teczka 281, k. 523.

${ }^{49}$ Pismo Świętosławskiego do Engberga, 19 X 1936 r. (kopia w jęz. francuskim), AAN, MWRiOP, teczka 281, k. 522.

${ }^{50}$ Min. Sandler w Polsce, „Kurier Warszawski”, 26 VIII 1937, nr 234, s. 12. 
kierowany przez J. Borowika wykazywał się aktywnością. Dyrektor Instytutu Bałtyckiego pozyskał do współpracy szwedzkiego historyka Nilsa Ahnlunda i ekonomistę Gunnara Myrdala. Od 1937 r. czasopismo Instytutu Bałtyckiego „Baltic Countries” zaczęto wydawać pod tytułem „Baltic and Skandinavian Countries”51. Wędkiewicz zamieszczał na łamach redagowanego przez siebie „Przeglądu Współczesnego" artykuły o problematyce szwedzkiej i stosunkach polsko-szwedzkich ${ }^{52}$.

Do wybuchu wojny utrzymywały się zasadnicze formy dotychczasowych polsko-szwedzkich kontaktów kulturalnych. MWRiOP finansowało lektorat języka polskiego w Lund i lektoraty języka szwedzkiego w Warszawie oraz języków skandynawskich w Poznaniu. Strona szwedzka subsydiowała lektorat języka polskiego w Sztokholmie i lektorat języka szwedzkiego na Uniwersytecie Jagiellońskim. Aktywnie funkcjonowała Biblioteka Szwedzka (działy: encyklopedyczny, naukowy i beletrystyczny) w Warszawie, kierowana przez B. Callemana ${ }^{53}$. Działalność kontynuowały pozarządowe towarzystwa współpracy polsko-szwedzkiej w obu krajach.

\section{Bibliografia}

\section{ŹródeA ARCHIWALNE}

Archiwum Akt Nowych w Warszawie

Ministerstwo Wyznań Religijnych i Oświecenia Publicznego, teczka 281.

Archiwum Instytutu Hoovera

Ambasada Polska w Wielkiej Brytanii, sygn. 800/33/0/-/112 (www.szukajwarchiwach.pl/800\#tab.zasoby).

51 B. Piotrowski, $W$ stużbie nauki $i$ narodu. Instytut Battycki $w$ latach 1925-1939, Poznań 1991, s. 264 i n.

52 Przykładowo: Z. Łakociński, Szwecja i Szwedzi, „Przegląd Współczesny” 1937, t. LXI, nr 180 (kwiecień), s. 97-106; J. B o r ow i k, Neutralność Skandynawii, „Przegląd Współczesny” 1937, t. LXII, nr 183 (lipiec), s. 35-56; K.G. Felle niu s, Literatura szwedzka a sprawa polska w 1863 r., „Przegląd Współczesny” 1938, t. LXVI, nr 196-197 (sierpień-wrzesień), s. 231-256; idem, Sprawa polska w szwedzkim Riksdagu w 1863 r., „Przegląd Współczesny” 1938, t. LXVII, nr 198 (październik), s. 101-113.

${ }^{53}$ Rocznik Polityczny i Gospodarczy PAT na r. 1939, Warszawa 1939, s. 592-593. 
Archiwum Uniwersytetu Jagiellońskiego

Materiały Stanisława Wędkiewicza, sygn. XXXIX.1.

Biblioteka Uniwersytetu Warszawskiego

Oddział Rękopisów, Materiały Karola Lutostańskiego, nr akc. 160.

\section{$\dot{\mathbf{Z}}_{\text {RÓDEA DRUKOWANE }}$}

Beck J., Przemówienia, deklaracje, wywiady 1931-1937, Warszawa 1938.

Borowik J., Pięć lat pracy Instytutu Bałtyckiego, 1927-1932, Toruń 1932.

Kronika Uniwersytetu Poznańskiego za rok szkolny 1934/ 35 za rektoratu prof. dr.

Stanisława Rungego i otwarcie roku szkolnego 1935/ 1936 w dniu 20 października 1935 roku, Poznań 1936.

Międzynarodowa Wspótpraca Intelektualna w roku 1931/32. Sprawozdanie Sekretarza Polskiej Komisji Międzynarodowej Wspótpracy Intelektualnej, Warszawa 1933.

„Nauka Polska. Jej potrzeby, organizacja i rozwój”. Materiały do spisu instytucji i towarzystw naukowych w Polsce. Suplement do t. VII, R. XII, Warszawa 1930.

Polska Komisja Międzynarodowej Współpracy Intelektualnej na progu 1936 r., Warszawa [grudzień] 1935.

Rocznik Polityczny i Gospodarczy PAT na r. 1939, Warszawa 1939.

\section{Prasa}

„Ilustrowany Kuryer Codzienny” 1932, 1935, 1936.

„Kurier Warszawski” 1935, 1937.

„Oświata i Wychowanie” 1935, 1936.

„Przegląd Współczesny” 1928, 1932, 1937, 1938.

\section{Opracowania}

Brzeziński A.M., Polska Komisja Międzynarodowej Wspótpracy Intelektualnej (1924-1939), Łódź 2001.

Ciesielski Z., Stanisław Wędkiewicz jako badacz i propagator Skandynawii, „Przegląd Zachodnio-Pomorski” 1969, z. 2, s. 83-92.

Czechowski J., Polsko-szwedzkie relacje ekonomiczne $w$ latach trzydziestych XX wieku w świetle polskich akt i opracowań, „Słupskie Studia Historyczne” 2016, nr 16, s. 103-116.

Helsztyński S., Stanisław Sawicki, „Pamiętnik Literacki” 1946, z. 3-4, s. 369-374.

Historia nauki polskiej, red. B. Suchodolski, t. V (1918-1951), cz. 1, Wrocław 1992. Jaworski P., Polska niepodległa wobec Skandynawii 1918-1939, Wrocław 2001.

Łossowski P., Z problemów wspótpracy naukowo-kulturalnej z zagranica w okresie II Rzeczypospolitej, „Dzieje Najnowsze” 1988, nr 1, s. 143-152.

Piotrowski B., W służbie nauki i narodu. Instytut Bałtycki w latach 1925-1939, Poznań 1991. 
Piskurewicz J., Prima Inter Pares. Polska Akademia Umiejętności w latach II Rzeczypospolitej, Kraków 1998.

Róziewicz J., Róziewicz H., Z dziejów międzynarodowych kontaktów naukowych Polski w latach 1919-1939, „Problemy Polonii Zagranicznej” 1974, t. IX, s. 339-378.

Staniszewski A., Działalność Towarzystwa Szwedzko-Polskiego na tle propagan$d y$ antypolskiej $w$ Szwecji $w$ okresie międzywojennym, „Zapiski Historyczne” 2010, t. LXXV, z. 1, s. 97-114.

Törnquist-Plewa B., Karl Gustaw Fallenius, wielki przyjaciel Polski, [w:] Zwierciadła Pólnocy. Zwiąki i paralele literatur polskiej i skandynawskiej, t. II, Warszawa 1992, s. 92-101.

Towarzystwo Polsko-Szwedzkie. Siedemdziesiąt lat działalności 1926-1996, Warszawa 1996. 